\title{
Cryopreservation Impacts Cell Functionality of Long Term Expanded Adipose-Derived Stem Cells
}

\author{
Ali El Othmani ${ }^{1}$, Sabrina Rouam ${ }^{1}$, Anass Abbad ${ }^{2,3}$, Chaimaa Erraoui ${ }^{1}$, Sara Harriba ${ }^{1}$, Hassan Boukind ${ }^{4}$, Jalal Nourlil ${ }^{3}$, Gabriel Malka ${ }^{5}$ and $^{2}$ \\ Loubna Mazini ${ }^{1,5^{\star}}$ \\ ${ }^{1}$ Stem Cells and Cell Therapy Laboratory, Pasteur Institute of Morocco, Casablanca, Morocco \\ ${ }^{2}$ Laboratory of Ecology and Environment, Ben M'sik, Hassan II University, Casablanca, Morocco \\ ${ }^{3}$ Medical Virology and BSL-3 Laboratory, Pasteur Institute of Morocco, Casablanca, Morocco \\ ${ }^{4}$ Center for Burns and Restorative Surgery, Ibn-Rochd University Hospital Center, Casablanca, Center for Regenerative Medicine, Casablanca, Morocco \\ ${ }^{5}$ Centre Interface Application Médicale (CIAM), Mohammed VI Polytechnic University, Ben Guerir, Morocco
}

\begin{abstract}
Objective: Adipose-Derived Stem Cells (ADSCs) are less immunogenic cells and have a heterogenic cytokine secretion profile making them a better candidate for cell-based immunotherapy. Even innately or stimulated, Interleukin-6 (IL-6) and Toll-like Receptor 2 (TLR2) secreted by ADSC were modulated and led to different inflammatory mechanism pathways through different inflammatory factors secretion. These properties can be very useful in the treatment of inflammation-associated chronic diseases. To be used, ex-vivo ADSC expansion is a critical issue prior to transplantation or cryopreservation. Functional cell changes have been reported during culture expansion being susceptible to interact with freezing/thawing effects leading to doubt on cell therapeutic outcomes. The aim of this study is to identify the effect of freezing/thawing at the different time point of expansion culture on IL-6 and TLR2 secretion.
\end{abstract}

Methods: ADSC were collected from young female donors, expanded in culture and cryopreserved in Foetal Bovine Serum (FBS) and Dimethylsulfoxide (DMSO) after each passage for 6 months to a year. ADSC was then tested for proliferation, clonogenicity, cytokine gene expression and assessment before cryopreservation (fresh) and after thawing and cultured until confluence (frozen/thawed). ADSC preserved at Passage 0 (P0) were thawed and tested after confluence at P1.

Results: Cryopreserved ADSC as P1 resulted in increased clonogenicity, total RNA and protein secretion compared to the fresh ones. Relative Quantification (RQ) and cytokine assessment of IL-6, IL-10, Tumor Necrosis Factor (TNF)- $\alpha$ and TLR2 revealed a moderate up-regulation of TLR2 while significantly higher IL- 6 secretion levels were observed in long term expanded and cryopreserved ADSC.

Conclusion: Our results suggested that cryopreserved ADSC long term expanded in culture were functionally different and might have impaired immunosuppressive properties through modulation of the inflammatory responses by IL- 6 and TLR2 activation.

Keywords: ADSC; Expansion culture; Cryopreservation; IL-6; TLR2; Inflammatory factors; FBS; Cell-based immunotherapy

Abbreviations: ADSCs: Adipose-Derived Stem Cells; IL:Interleukin; TLR2: Toll-like Receptor 2; DMSO: Dimethylsulfoxide; TNF- $\alpha$ : Tumor Necrosis Factor- $\alpha$; AT: Adipose Tissue; MSC: Mesenchymal Stromal/ Stem Cell; SVF: Stromal Vascular Fraction; GVHD: Graft Versus Host Disease; CPA: Cryoprotective agents; TGF- $\beta$ : Tumor Growth Factor- $\beta$; FBS: Foetal Bovine Serum; CFU-F: Colony Forming Unit-Fibroblasts; P: Passage; RQ: Relative Quantification

\section{Introduction}

Adipose Tissue (AT) has gained more interests since reported to be enriched in multipotent stem cells $[1,2]$. These cells having Mesenchymal Stem Cell (MSC) characteristics were called ADSCs and were identified within the freshly isolated Stromal Vascular Fraction (SVF) which contains also smooth muscle, circulating cells as leukocytes, endothelial and hematopoietic progenitors, pericytes, fibroblasts and pre-adipocytes $[3,4]$. Their ability to differentiate into different cells belonging to mesodermic, endodermic and ectodermic origins has been largely documented in the literature increasing their attractiveness in tissue repair and regenerative medicine [1,5-9].

ADSC are known to secrete a large panel of cytokines and chemokines and their ability to produce inflammatory factors innately or after stimulation has been investigated. Native or auto-induced
ADSC secreted IL-8, TNF- $\alpha$ [10-13], IL-10, TLR2 [14,15] and higher levels of IL-6 [15-17], being involved for distinct inflammatory signaling pathways. Also, in response to inflammatory stimuli, ADSC inhibited pro-inflammatory factors while increased that of the anti-inflammatory cytokines IL-10 and the TLR2 in vitro as well as in vivo [15-20].

Nevertheless, it has been reported that stimulation of distinct TLR elicited different inflammatory signaling pathways leading to differentially expressed inflammatory factors and influencing the ability of MSC to suppress immune cell proliferation [21]. Controlling these inflammatory properties might be very helpful in the treatment of perinatal morbidities-associated inflammation of colitis, respiratory

*Corresponding author: Loubna Mazini, Centre Interface Application Médicale (CIAM), Mohammed VI Polytechnic University, Ben Guerir, Morocco, Tel: +212 525-072700; E-mail: loubna.mazini@um6p.ma; loubna.cell01@gmail.com

Received January 08, 2019; Accepted January 30, 2019; Published February 05, 2019

Citation: Othmani AE, Rouam S, Abbad A, Erraoui C, Harriba S, et al. (2019) Cryopreservation Impacts Cell Functionality of Long Term Expanded AdiposeDerived Stem Cells. Stem Cell Res Ther 9: 445. doi: 10.4172/2157-7633.1000445

Copyright: (c) 2019 Othmani AE, et al. This is an open-access article distributed under the terms of the Creative Commons Attribution License, which permits unrestricted use, distribution, and reproduction in any medium, provided the original author and source are credited. 
distress, Crohn's disease, and lupus erythematosus. However, Graft Versus Host Disease (GVHD) has been the most studied so far. The biological mechanisms underlying ADSC immunological benefit observed have been variable over the clinical studies and might interfere with the cryopreservation protocols used to pool these cells. Being uncultured or expanded at a different time, ADSC presented different cell profiles having thus multiple therapeutic outcomes. It's widely accepted that ADSC proliferation changed significantly within successive culture passages regarding stem cell-associated profile and multilineage differentiation ability [22-24], reflecting functional cell changes relating themselves to different regulation pathways and effectiveness. This fact was reported for fresh ADSC and might not be similar when using cryopreserved/thawed cells [23], suggesting an additional effect of Cryoprotective Agents (CPA) and the time storage to culture passage on the paracrine activity and response efficiency of fresh ADSC.

Because of cryopreservation protocols are mostly reported for freshly isolated ADSC or those derived from primary culture, ADSC efficiency and inflammatory cytokines profile might be modulated by the freezing at the different time point of expansion culture and are yet to be determined. Most of them were reported to impact negatively ADSC cellular viability, Colony Forming Unit-Fibroblast (CFU-F) ability, differentiation potency, phenotypic and gene expression and secretion profile [25-29]. When separated from their microenvironment, ADSC cryopreservation outcomes were also differentially appreciated [22,3032]. ADSC might be exposed to exogenous factors such as draining reagents since collection suggesting that the time delay between their collection and separation might be associated with their efficiency.

All these parameters should be addressed to master ADSC use for therapeutic applications. In our study, we attempt to define the effects of a widely used freezing protocol at a different culture time point on ADSC yield, clonogenicity, protein, and total RNA (tRNA) secretion, and on IL- 6 and TLR2 secretion.

\section{Materials and Methods}

\section{Collection of AT}

AT collection process has been endorsed by the institutional requirements of the Institut Pasteur Ethical Committee. Lipoaspirates were performed on consent young women aged from 18-48 years old undergoing esthetic treatments as previously described [33]. Samples were collected from abdominal subcutaneous tissue and stored at $+4^{\circ} \mathrm{C}$ before and during transfer to the laboratory. More than 30 samples were collected and each of them was manipulated and tested separately.

\section{Separation of the SVF}

AT from each donor was separated on four identical samples. All the samples were placed at $+4^{\circ} \mathrm{C}$ during either one day $(24 \mathrm{~h})$, two days (48 h), or five days $(72 \mathrm{~h})$, the last one was manipulated within $12 \mathrm{~h}$ after collection. Cells were washed and digested with collagenase II (Gibco, Invitrogen) at $2.5 \%$ and incubated at $37^{\circ} \mathrm{C}$ for $30 \mathrm{~min}$. At the end of incubation, cells were washed, and the final pellet was suspended in DMEM medium (Gibco, Invitrogen). Cells were tested for viability using the trypan blue (Gibco, Invitrogen) dye exclusion method. Only SVF processed less than $12 \mathrm{~h}$ were seeded in culture for ADSC expansion and cryopreservation.

\section{In-vitro ADSC expansion}

SVF from lipoaspirates were cultured in $75 \mathrm{~cm}^{2}$ flasks at $2 \times 10^{4} /$ $\mathrm{cm}^{2}$ density. Culture medium containing DMEM supplemented with 10\% FBS (Gibco, Invitrogen), 2\% Penicillin-streptomycin (Gibco, Invitrogen), and $1 \%$ fungizone (Gibco, Invitrogen) was added. Flasks were incubated for confluence in a humidified atmosphere at $37^{\circ} \mathrm{C}$ and $5 \% \mathrm{CO}_{2}$. For successive passages, adherent layers were treated with trypsin-EDTA (Gibco, Invitrogen), and cells were tested for viability before seeding in culture. Cell expansion was maintained up to $4^{\text {th }}$ passages, and ADSC aliquots were cryopreserved after each passage.

\section{Cryopreservation protocol}

Freshly isolated SVF and expanded ADSC (P0, P1, P2, P3) were used for cryopreservation. The freezing medium was prepared as $90 \%$ FBS and $10 \%$ DMSO. Cell suspensions were washed at $+4^{\circ} \mathrm{C}$ and kept on ice and were assimilated at $5 \times 10^{6} \mathrm{cell} / \mathrm{ml}$ for SVF and $1 \times 10^{6} \mathrm{cell} /$ $\mathrm{ml}$ for expanded ADSC. Cryopreservation medium was added gently to the vials transferred rapidly latter at $-20^{\circ} \mathrm{C}$ for $24 \mathrm{~h}$ and in a freezing system ensuring a steady freezing rate of $-1^{\circ} \mathrm{C} / \mathrm{min}$ down to $-80^{\circ} \mathrm{C}$. Cells were frozen at $-80^{\circ} \mathrm{C}$ for 6 months to a year.

\section{Thawing}

Cells from different passages (SVF, P0, P1, P2, P3) were rapidly thawed by immersing the vials in a water bath for $2 \mathrm{~min}$ at $37^{\circ} \mathrm{C}$ and re-suspended in DMEM supplemented with 20\% FBS. Cells were tested for viability with the trypan blue dye exclusion assay and seeded in culture for confluence. One day after seeding, DMEM with 20\% FBS was replaced by the standard culture medium. Frozen/thawed SVF fractions were maintained until confluence and became P0. Figure 1 summarized our process to compare expanded ADSC properties before and after cryopreservation.
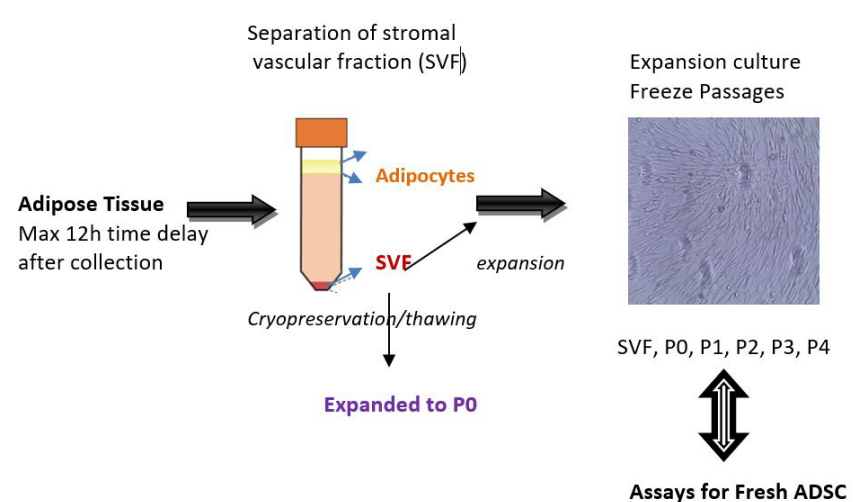

Figure 1: Schema translating analysis protocol of ADSC before and after cryopreservation. 


\section{Quantitative RT-PCR analysis}

Total RNA was extracted from fresh SVF, expanded ADSC before and after freezing using General RNA extraction kit (NeoBiotech, France) as per manufacturer instructions. RNA purity and integrity were tested by gel migration before use or preservation at $-80^{\circ} \mathrm{C}$. Quantitative RT-PCR reactions were prepared as $20 \mu \mathrm{l}$ reaction using a Transcript II Green One-Step qRT-PCR SuperMix (Trans, Transbionova, USA), run on a real-time FAST ABI Prism 7500 machine (Applied Biosystems) and analyzed with comparative CT $(\Delta \Delta \mathrm{CT})$ in the V.2.0.6 Software. Transcript levels expression was determined by normalizing to values of GAPDH expression. Results are means of three replicates. Forward and Reverse specific primers used were: IL-6 (F: ATTAGAGTCTCAACCCCCAATAAA, R: CTGAGATGCCGTCGAGGATG), IL-10 (F: GCCTAACATGCTTCGAGATC, R: TGATGTCTGGGTCTTGGTTC), TLR-2 (F: GCCTACTGGGTGGAGAACCT, R: GGCCACTCCAGGTAGGTCTT), TNF- $\alpha$ (F: TCTTCTCGAACCCCGAGTGA, R: CCTCTGATGGCACCACCAG) and GAPDH as control assays (F: GAAGGTGAAGGTCGGAGT, R: GAAGATGGTGATGGGATTTC). Cycling parameters were $50^{\circ} \mathrm{C}$ for $5 \mathrm{~min}$ and $94^{\circ} \mathrm{C}$ for $30 \mathrm{~s}$ followed by $45 \mathrm{cycles}$ of $94^{\circ} \mathrm{C}$ for $5 \mathrm{~s}$ and $60^{\circ} \mathrm{C}$ for $34 \mathrm{~s}$.

\section{CFU-F assay}

Expanded ADSC before and after freezing were plated in triplicate in $57 \mathrm{~cm}^{2}$ dishes with 3 different dilutions (5000-1000-100 cells) in DMEM containing 1\% Penicillin-streptomycin and 10\% of ADSCconditioned media (from SVF fresh cultures). Dishes were seeded in humidified $5 \% \mathrm{CO}_{2}$ atmosphere at $37^{\circ} \mathrm{C}$ for $10-12$ days. Plates were then washed with PBS and fixed with Formaldehyde (Sigma, Aldrich) before staining with Crystal Violet solution (Sigma Aldrich). A colony consisting of more than 50 cells was defined as a CFU-F. Plating efficiency was estimated as colonies per number of initially plated cells $\times 100 \%$.

\section{Relative total RNA (tRNA) and protein concentration measurements}

Different culture passages were tested for protein concentration by UV Absorbance at $280 \mathrm{~nm}$. Culture supernatants were analyzed in the UV-160A spectrometer (Shimadzu) and absorbance calculated as $A=\log 10 / \mathrm{I}$. Proteins level was reported according to $1 \mathrm{~A}=1 \mathrm{ng} / \mu \mathrm{l}$ supernatant. Total RNA quantification was performed at $260 \mathrm{~nm}$ in same culture supernatants according to the correlation $1 \mathrm{~A}=33 \mathrm{ng} / \mu \mathrm{l}$. Measurements were obtained in triplicate for each sample.

\section{Supernatant cytokine assessment}

Supernatants form fresh and frozen/thawed ADSC were collected, aliquoted and frozen at $-80^{\circ} \mathrm{C}$ for further analysis. All experiments were performed in duplicate. For each culture passage, three samples were analyzed. Human IL-6 Elisa kit (Neo Biotech), IL-10 Elisa kit (Neo Biotech), TNF- $a$ Elisa kit (Aviva Systems Biology) and TLR2 Elisa kit (ElabScience) were used according to the manufacturer's instructions. Optical densities were read at $450 \mathrm{~nm}$, and results reported as $\mathrm{pg} / \mathrm{ml}$.

\section{Statistics}

Differences were analyzed by Student T-test for significance between fresh and frozen/thawed ADSC at different culture passage regarding parameters (cell yield, CFU-F, tRNA and proteins, inflammatory factors $R Q)$. A value of $\mathrm{P}<0.05$ was shown significantly.

\section{Results}

\section{Relationships between time delay before processing, cell yield and ADSC recovery in SVF enriched lipoaspirates}

After liposuction, samples maintained less than $12 \mathrm{~h}$ at $+4^{\circ} \mathrm{C}$ remained more enriched in cell components as shown in Table 1. Processing one day after collection resulted in 5-fold significant decrease in cell yield. The time delay before processing was inversely related to the yield of SVF and to ADSC recovery in primary culture. The more rapidly processed, the more SVF enriched in ADSC with a significant relevant yield in less than $12 \mathrm{~h}$ group. Moreover, ADSC spent more time in culture for confluence with increasing time delay.

\section{Cryopreservation impact on ADSC yield in expansion culture}

In Figure 2, ADSC yield appeared not affected by cryopreservation

\begin{tabular}{|c|c|c|c|c|c|}
\hline & Cell yield $10^{7} / \mathrm{ml}$ & Cells in SVF $10^{7} / \mathrm{cm}^{2}$ & ADSC $10^{7} / \mathrm{cm}^{2}$ in $\mathrm{PO}$ & Days for confluence & $n$ \\
\hline Less than $12 \mathrm{~h}$ & $5228.7 \pm 9545$ & $931.6 \pm 1678$ & $86 \pm 71$ & $8 \pm 1$ & 12 \\
\hline $24 \mathrm{~h}$ after & $1216 \pm 918^{*}$ & $92 \pm 16.2$ & $34 \pm 52^{*}$ & $9 \pm 1$ & 8 \\
\hline $48 \mathrm{~h}$ after & $13 \pm 16$ & $11 \pm 9$ & $15 \pm 21^{*}$ & $11.4 \pm 2.7$ & 5 \\
\hline $72 \mathrm{~h}$ after & $2 \pm 4.5$ & $2 \pm 1.5$ & $1.2 \pm 0.8$ & $14.2 \pm 3.2$ & 6 \\
\hline
\end{tabular}

Table 1: Cell yield and ADSC recovery regarding time delay before processing of lipoaspirates. Results are means \pm SD, and $n$ is the sample size.

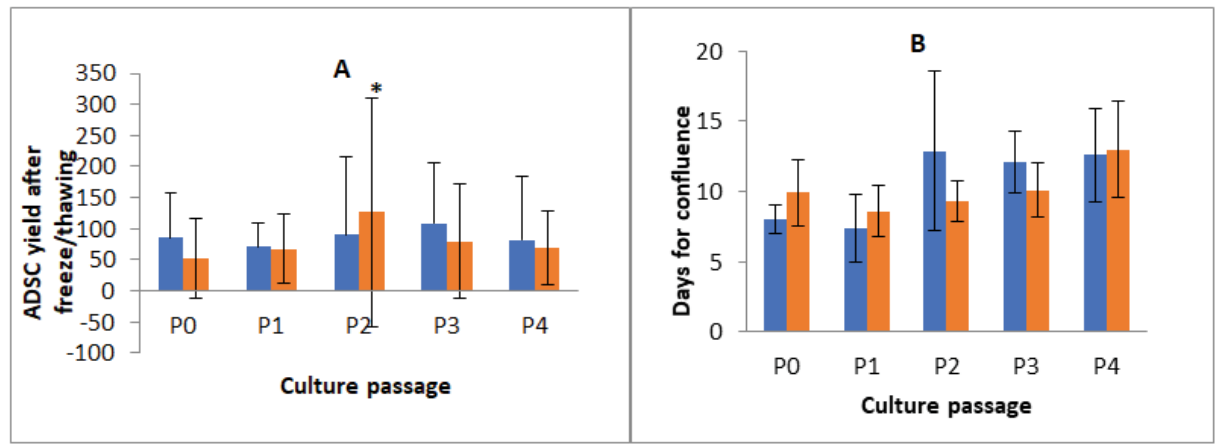

Figure 2: A) ADSC yield before (blue bars for fresh) and after freeze/thawing (red bars) at each passage as $10^{7}$ cells $/ \mathrm{cm}^{2}$; B) Days for confluence were estimated. Results are means \pm SD $(n=12)$. ${ }^{*} P<0.05$ 
except when frozen/thawed ADSC was derived from P1 and estimated after culture at P2 (A). At this passage, even yield variability is important; cells were significantly more proliferative than fresh ones. Early expanded ADSC seemed to confluent slowly after thawing and this trend was inverted after.

\section{The clonogenic activity of ADSC and cryopreservation}

Clonogenic activity estimated by plating efficiency showed that fresh ADSC formed significantly more colonies at P0 (Figure 3). This activity appeared maintained between two groups while at P2, frozen/ thawed ADSC demonstrated significantly higher plating efficiency, which was not relevant for the rest of culture.

\section{Cryopreservation effect on relative protein and tRNA concentration in expanded ADSC}

Fresh ADSC secretion level decreased progressively during culture when considering both protein and tRNA (Figures $4 \mathrm{~A}$ and $4 \mathrm{~B}$ ). However, proteins were significantly more secreted at $\mathrm{P} 0$ and their concentrations were relevant at $\mathrm{P} 2$ for the frozen/thawed ADSC (Figure 4A). Cryopreserved ADSC secreted significantly more tRNA at P1 and P2 (Figure 4B).

\section{Quantitative analysis of secreted inflammatory factors (qRT-} PCR)

The results summarized in Figure 5 showed that RQ of IL-6, IL-10, TNF- $\alpha$, and TLR 2 were differently modulated during culture expansion

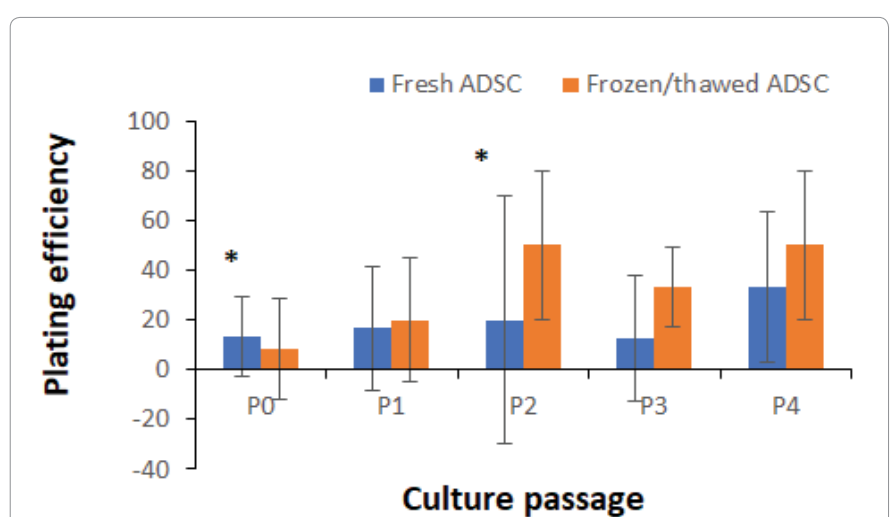

Figure 3: Comparison of clonogenic activity of fresh and frozen/thawed ADSC at every culture passage calculated as plating efficiency $(\%)$. Results are means $\pm \mathrm{SD}(\mathrm{n}=9) .{ }^{*} \mathrm{P}<0.05$ and after cryopreservation. Culture expansion did not impact mRNA levels of the estimated factors by fresh ADSC. Their intensity was otherwise weakly expressed when normalized to that of SVF expressions. However, TNF- $\alpha$ and TLR2 mRNA expression increased at P3 for frozen/thawed ADSC but appeared obvious when adjusted to the significantly higher levels of IL-6 RQ. In the same way, RQ changes in IL-10 expression should not be at detectable levels of those of IL-6.

\section{Comparison of cytokine expression in culture supernatants of fresh and frozen/thawed ADSC}

Figure 6 showed that IL-10 and TNF- $\alpha$ were secreted at a lower level throughout the culture. TLR2 was moderately released and its secretion increased by $\mathrm{P} 3$ and especially P4 by the frozen/thawed cell population. Both populations of ADSC released higher quantities of IL-6 in culture supernatants compared to the other cytokine levels. However, cryopreservation of ADSC at P3 extremely and significantly increased IL-6 secretion level (estimated at P4).

\section{Discussion}

In promoting cell-based therapies, the emerging interest in ADSC should not be impaired by factors influencing their proliferation and immunosuppressive potency. Among these factors, patient age, gender, and derivation site are altogether critical in ADSC behaviors as reported $[22,34,35]$. To overcome these factors, our ADSC were collected from abdominal subcutaneous tissue of young females as recommended [36]. However, the patient's associated factors could not be excluded as having an unexpected reaction on frozen/thawed ADSC behaviors.

\section{Conclusion}

In the present work, we concluded that $12 \mathrm{~h}$ is the maximum time delay to have SVF fractions containing higher frequencies of ADSC being expandable in expansion culture. Other findings reported that this time might be conducted to $24 \mathrm{~h}$ without any loss in ADSC recovery [37].

Our results demonstrated that ADSC exhibited typical MSC characteristics and phenotypes, and their viability was optimum before $(>90 \%)$ and after cryopreservation at $0.5-1 \times 10^{6} / \mathrm{ml}(>85 \%)$ (data not shown). In addition, the FBS-cryopreservation containing protocol used has consequently demonstrated its efficacy in terms of viability, proliferative, clonogenic and paracrine activity. In this study, we attempt to identify a better freezing time point within the culture to cryopreserve ADSC having high proliferative and immunosuppressive activities.

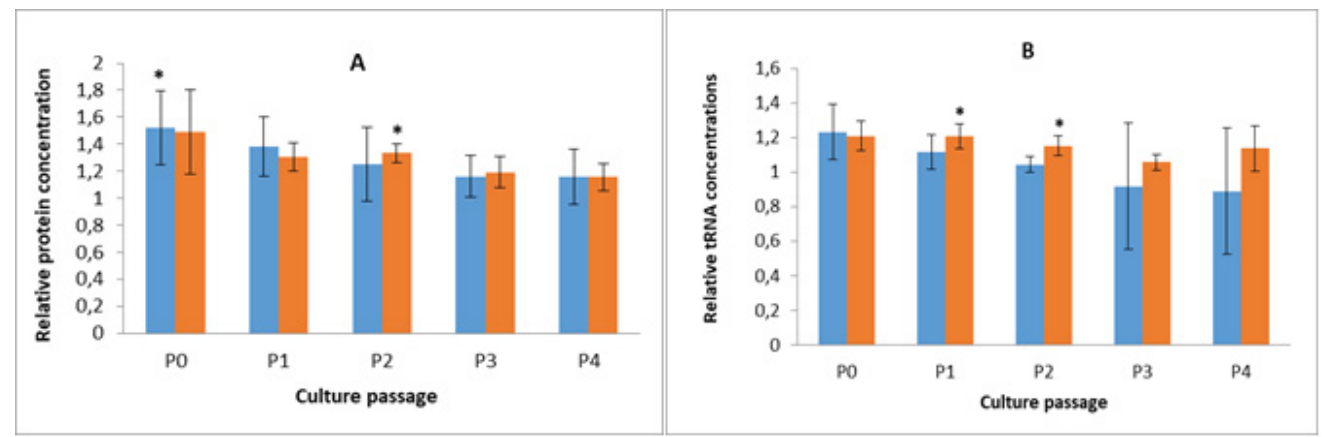

Figure 4: Relative (A) protein and (B) tRNA concentrations in culture supernatants of freshly isolated (blue bars) and cryopreserved ADSC (red bars) at different culture passages evaluated at $280 \mathrm{~nm}$ and $260 \mathrm{~nm}$, respectively. Results are means $\pm \mathrm{SD} \mathrm{ng} / \mathrm{ml}(\mathrm{n}=12)$. ${ }^{*} \mathrm{P}<0.05$ 


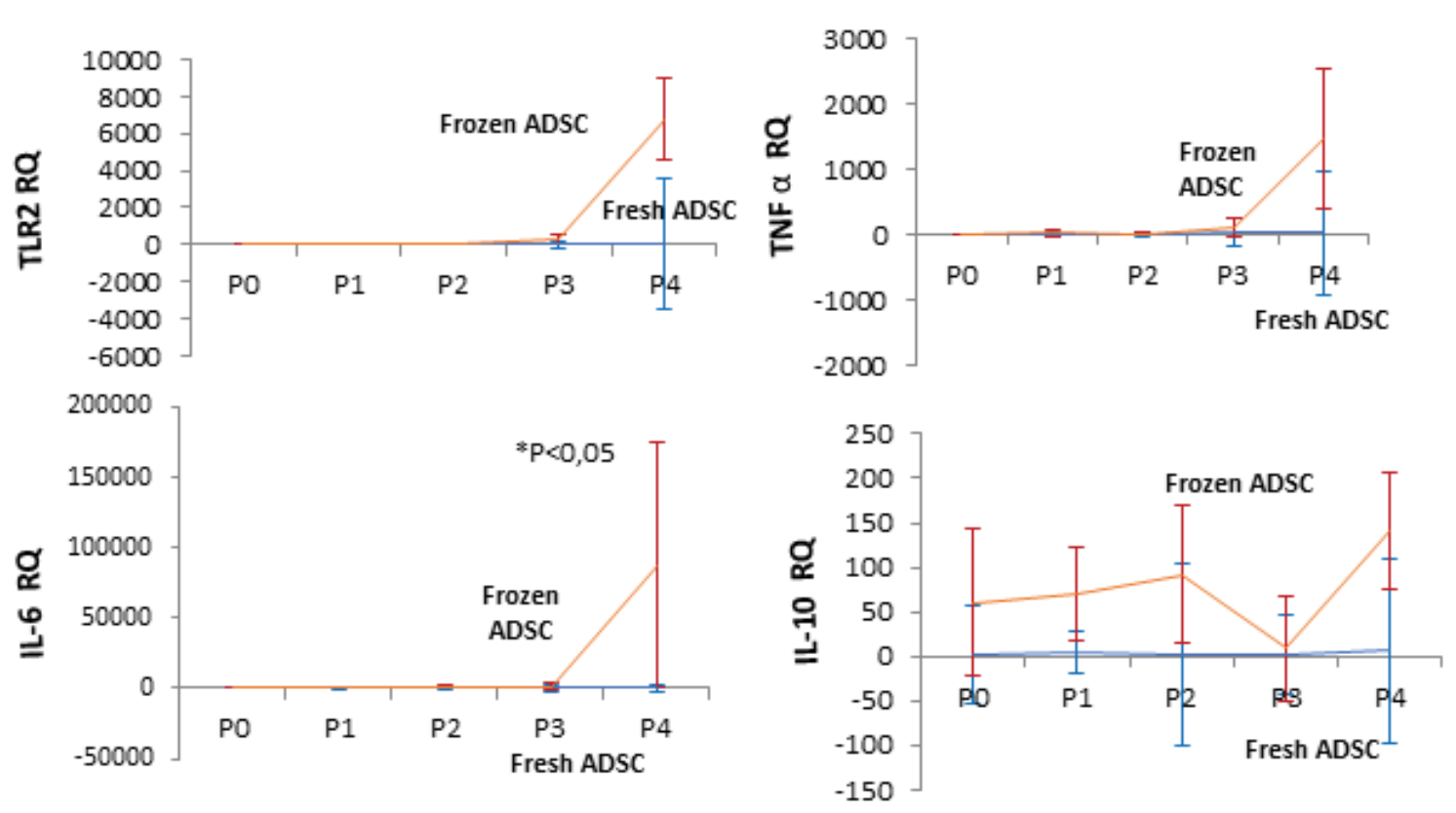

Figure 5: IL-6, IL-10, TNF- $\alpha$ and TLR2 mRNA expressions were evaluated after each culture passage in fresh and frozen/thawed ADSC through $\triangle \triangle \mathrm{Ct}$ comparation. Data are displayed as the means $\pm S D$ of triplicates and calculated $R Q$ values were normalized to SVF expression levels.
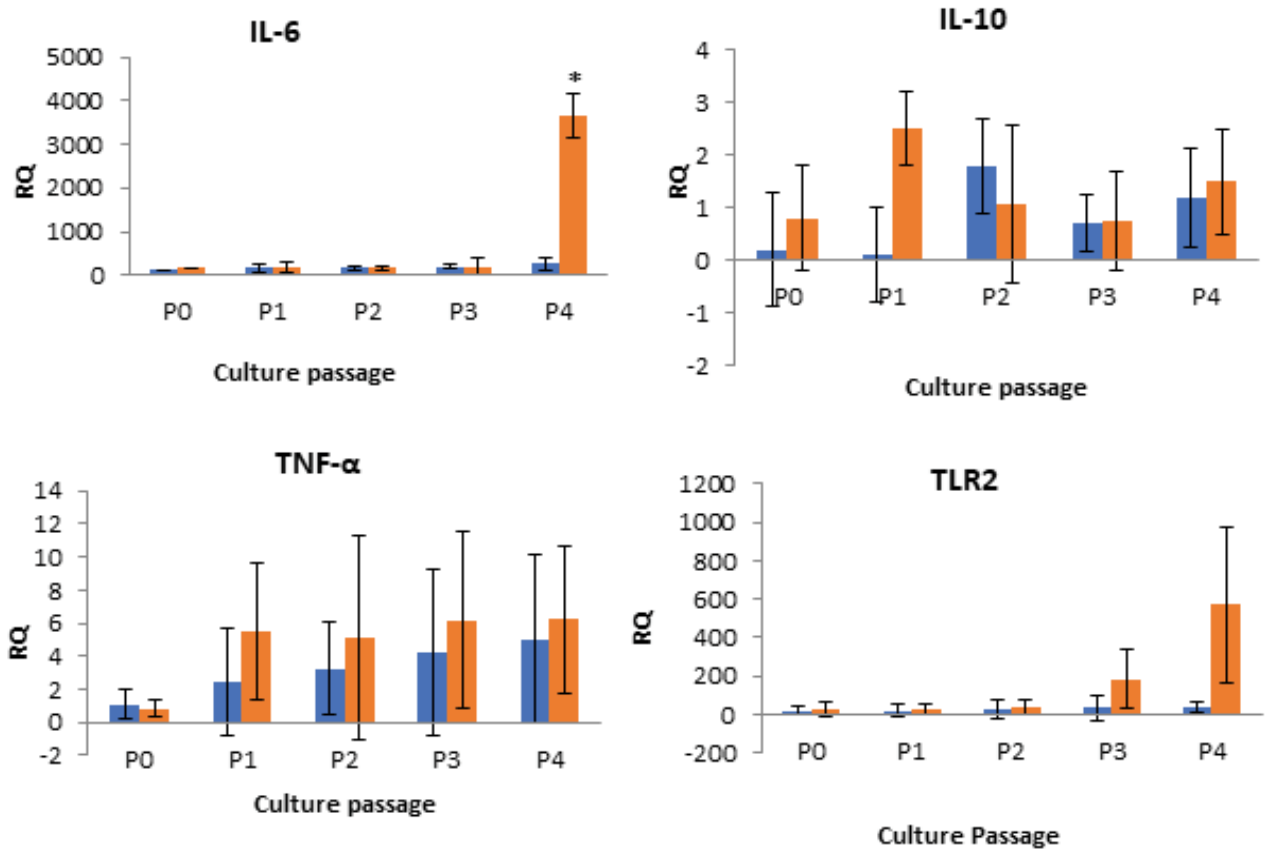

Figure 6: Concentrations level of Fresh (blue bars) and frozen/thawed (red bars) ADSC-derived cytokines in culture supernatants estimated as pg/ml. Results are means $\pm \operatorname{SD}(n=3) .{ }^{*} P<0.05$.

When ADSC was stored one day at $-20^{\circ} \mathrm{C}$ followed by $-80^{\circ} \mathrm{C}$ for up to 6 months, no deleterious effect on viability, clonogenicity or cytokine production were shown, suggesting that avoiding $-196^{\circ} \mathrm{C}$ storage did not impact on cell physiology. These results are in accordance with other findings where cryopreservation protocols using DMSO at $-80^{\circ} \mathrm{C}$ or $-196^{\circ} \mathrm{C}$ are equivalent without influencing differentiation ability and cell phenotype of ADSC [22,23,26-30].

Otherwise, whether ADSC cryopreservation within their SVFrelated microenvironment was expected to impact their therapeutic outcome after thawing remained unclear and should be also identified. 
Autologous fat cryopreserved with CPA at $-20^{\circ} \mathrm{C},-80^{\circ} \mathrm{C}$ and $-196^{\circ} \mathrm{C}$ for 2 and 4 weeks exhibited no differences in cell viability, but when these cryopreserved fats were transplanted, engraftment was found reduced and post-thaw functional isolated ADSC was also limited in number $[25,38,39]$. These findings suggested that isolating and expanding ADSC prior to cryopreservation might be of clinical interest.

There is convincing evidence that the duration of culture expansion influenced ADSC phenotype and ascertained the relationship between morphological changes and physiological effect [22,40-42] which might explain the mechanisms whereby ADSC ensure tissue repair. Nevertheless, cryopreservation effect on expanded ADSC physiology should not be excluded adding to the complexity of their physiologymicroenvironment interactions. Firstly, we have reported that cryopreservation of expanded ADSC from P0 to P3 (estimated at P1 to $\mathrm{P} 4$ after thawing) did not impact the immediate post-thawing viability. However, these cells seemed to be slow to confluent when compared to fresh ones, except for P1 where post-thawing ADSC (P2) proliferated significantly at higher frequencies in a shorter time. Frozen ADSC at P1 can generate more than $1 \times 10^{9}$ in a limited time after thawing and expanding to P2. This growth kinetic might be beneficial in allogenic applications where increased cell doses are needed at a specific time point after cryopreservation.

On another side, fresh ADSC clonogenicity increased during culture confirming their physiological changes, but interestingly, our cryopreservation process significantly decreased ADSC clonogenicity when derived from SVF (estimated at P0), and significantly increased it for P1-derived cells (estimated at P2), confirming the stemness profile of frozen/thawed ADSC at early culture passage and their commitment in later ones accordingly to fresh ones. These results suggested also that cryopreservation did not speed up ADSC commitment status.

The paracrine profile of frozen/thawed ADSC paved the way to clonogenicity and showed a significant increase in protein and tRNA reflecting an accumulation of membrane proteins and or an increase within culture supernatant of functional proteins improving thus different mechanism pathways. For another point of view, frozen/ thawed ADSC were more productive when derived from P1, and the most produced factors might be different from the inflammatory factors we estimated and can be related to another biological process as cell homing and migration. Quantitative RT-PCR results and cytokines assessment confirmed that IL- 6 mRNA was predominantly present after cryopreservation as compared to IL-10 and TLR2. We suggested that cryopreservation might overexpress or up-regulate IL-6 expression, probably through amplification by TLR2 induction. Even though early culture stage did not influence significantly IL-10, TNF- $\alpha$ and TLR2 mRNA secretion, freezing ADSC at latest culture passage was accompanied by enhanced IL- 6 and TLR2 expression levels. This increase might not be explained by using FBS within culture medium conditions even it contains soluble factors known to be cross-reactive to human antibodies [43], being present with ADSC contact early in culture and in cryopreserving media. We reported big variability within ADSC samples in cytokine levels especially for IL- 6 after thawing; this fact might be coincident with a different auto-induction cytokine secretion capability dependent on initial patient's associated factors.

IL- 6 cytokine effects on innate and adaptive immunity have been investigated within their both pro-inflammatory and anti-inflammatory contexts, but mostly presented as a pro-inflammatory cytokine having the ability to dually enforce or suppress immune responses depending on conditions. This cytokine is largely secreted by fresh ADSC than IL-10 and TNF- $\alpha[15-17,44]$, however, these concentration levels were reported for fresh expanded ADSC and remained relatively lowers when compared to those of cryopreserved ADSC. Indeed, cryopreservation increased IL- 6 and TLR2 at both mRNA and protein levels, especially after P2 expansion. Using frozen/thawed ADSC previously expanded up to P2 might raise confusion on their therapeutic benefit in cellbased immunotherapy. In the same way, most of the functional studies on ADSC therapeutic use missed reporting their temporal expansion culture or thawed state, creating doubt on their real benefit. In spite of being the unique alternative to pool these cells for transplantation, cryopreservation process might account for heterogeneous responses observed for ADSC clinical outcomes, even worse when applied at allogeneic setting. Interestingly, for more therapeutic benefit when IL-6 antagonists have been used, disease improvement and patient wellbeing have been reported [45].

On another side, TLRs were presented as the major actor in the inflammatory effect mediated by IL-6. Activation of TLRs on MSC has been shown to trigger the transcription factor NF- $\kappa \mathrm{B}$ inducing the secretion of pro-inflammatory cytokines, including TNF- $\alpha$, IL- $1 \beta$, IFN- $\gamma$, and IL- 6 , thereby promoting the immune response [46]. There is also evidence that perpetual inflammation associated with chronic inflammatory diseases resulted on permanent stimulation of TLR by their ligands continuously present within the inflamed environment, leading to up-regulation of IL-6 release [21]. Adding to that, ADSC might be auto-induced by Tumor Growth Factor- $\beta$ (TGF- $\beta$ ), TLR2, TNF-aresulting in different inflammatory factors secretion panel as already reported [16,47-49]. In serum-free conditions, ADSC also secreted IL-6, IL-10, and TGF- $\beta$ [44]. Distinct inflammatory signaling pathways were thus activated impacting the immunosuppressive activity of ADSC. These changes in paracrine signaling mechanism might be capable of modulating or reversing the polarization of macrophages into the immunosuppressive phenotype [50]. Other findings reported that IL-6 and TLR2 were responsible for monocytes migration $[16,17]$.

In our study, the increased level of TLR2 within culture might suggest an up-regulation of IL- 6 expression and release by ADSC. This improved pro-inflammatory secretion provides insights for further investigations relative to cell-based immunotherapy for inflammatory manifestations such as Crohn's disease, colitis, and GVHD. This suggests that controlled temporal ADSC cryopreservation might avoid the need of cytokines supplementation to the graft or inversely the use of antagonists as immunosuppressive factors to dampen local inflammation and restore the therapeutic benefit of ADSC. Our findings suggested that cryopreservation of long term expanded ADSC can impair their immunosuppressive efficacy with major concerns regarding safety therapeutic issues.

\section{Conflict of Interest}

Declarations of interest: none.

\section{Acknowledgment}

This work was supported by the Institut Pasteur Maroc, Casablanca, Morocco and the Centre Interface Application Médicale (CIAM), Université Mohammed VI Polytechnique, Ben Guérir, Morocco.

\section{References}

1. Zuk PA, Zhu M, Ashjian P, De Ugarte DA, Huang Jl, et al. (2002) Human adipose tissue is a source of multipotent stem cells. Mol Biol Cell 13: 42794295. [PubMed]

2. Ryu YJ, Cho TJ, Lee DS, Choi JY, Cho J (2013) Phenotypic characterization and in vivo localization of human adipose-derived mesenchymal stem cells. Mol Cells 35: 557-564. [PubMed]

3. Zuk PA, Zhu M, Mizuno H, Huang J, Futrell JW, et al. (2001) Multilineage cells 
Citation: Othmani AE, Rouam S, Abbad A, Erraoui C, Harriba S, et al. (2019) Cryopreservation Impacts Cell Functionality of Long Term Expanded Adipose-Derived Stem Cells. Stem Cell Res Ther 9: 445. doi: 10.4172/2157-7633.1000445

from human adipose tissue: implications for cell-based therapies. Tissue Eng 7: 211-228. [PubMed]

4. Gimble JM, Katz AJ, Bunnell BA (2007) Adipose-derived stem cells for regenerative medicine. Circ Res 100: 1249-1260. [PubMed]

5. Rodriguez AM, Elabd C, Amri EZ, Ailhaud G, Dani C (2005) The human adipose tissue is a source of multipotent stem cells. Biochimie 87: 125-128. [PubMed]

6. Safford KM, Hicok KC, Safford SD, Halvorsen YD, Wilkison WO, et al. (2002) Neurogenic differentiation of murine and human adipose-derived stromal cells. Biochem Biophys Res Commun 294: 371-379. [PubMed]

7. Seo MJ, Suh SY, Bae YC, Jung JS (2005) Differentiation of human adipose stromal cells into hepatic lineage in vitro and in vivo. Biochem Biophys Res Commun 328: 258-264. [PubMed]

8. Moseley TA, Zhu M, Hedrick MH (2006) Adipose-derived stem and progenitor cells as fillers in plastic and reconstructive surgery. Plast Reconstr Surg 118 121-128. [PubMed]

9. Elman JS, Li M, Wang F, Gimble JM, Parekkadan B (2014) A comparison of adipose and bone marrow-derived mesenchymal stromal cell secreted factors in the treatment of systemic inflammation. J Inflamm (Lond) 11: 1. [PubMed]

10. Eto $H$, Kato H, Suga H, Aoi N, Doi K, et al. (2012) The fate of adipocytes after nonvascularized fat grafting: evidence of early death and replacement of adipocytes. Plast Reconstr Surg 129: 1081-1092. [PubMed]

11. Bae YC, Song JS, Bae SH, Kim JH (2015) Effects of human adipose-derived stem cells and a stromal vascular fraction on cryopreserved fat transfer. Dermatol Surg 41: 605-614. [PubMed]

12. Ha KY, Park H, Park SH, Lee BI, Ji YH, et al. (2015) The Relationship of a combination of human adipose tissue-derived stem cells and frozen fat with the survival rate of transplanted fat. Arch Plast Surg 42: 677-685. [PubMed]

13. Amable PR, Teixeira MVT, Carias RBV, Granjeiro JM, Borojevic R (2014) Protein synthesis and secretion in human mesenchymal cells derived from bone marrow, adipose tissue and Wharton's jelly. Stem Cell Res Ther 5: 53. [PubMed]

14. Gonzalez-Rey E, Anderson P, González MA, Rico L, Büscher D, et al. (2010) Human adipose-derived mesenchymal stem cells reduce inflammatory and $T$ cell responses and induce regulatory $T$ cells in vitro in rheumatoid arthritis. Ann Rheum Dis 69: 241-248. [PubMed]

15. Sangiorgi B, Panepucci RA (2016) Modulation of immunoregulatory properties of mesenchymal stromal cells by toll-like receptors: potential applications on GVHD. Stem Cells Int 2016: 9434250.

16. Rodríguez T, M Saldías A, Irigo M, Zamora JV, Perone MJ, et al. (2015) Effect of TGF- $\beta 1$ stimulation on the secretome of human adipose-derived mesenchymal stromal cells. Stem Cells Transl Med 4: 894-898. [PubMed]

17. Lee MJ, Kim J, Kim MY, Bae YS, Ryu SH, et al. (2010) Proteomic analysis of tumor necrosis factor-alpha-induced secretome of human adipose tissuederived mesenchymal stem cells. J Proteome Res 9: 1754-1762. [PubMed]

18. Yang J, Zhang Y, Zang G, Wang T, Yu Z, et al. (2018) Adipose-derived stem cells improve erectile function partially through the secretion of IGF-1, bFGF, and VEGF in aged rats. Andrology 6: 498-509. [PubMed]

19. Deezagi A, Shomali S (2018) Prostaglandin F-2a stimulates the secretion of vascular endothelial growth factor and induces cell proliferation and migration of adipose tissue-derived mesenchymal stem cells. Cell J 20: 259-266. [PubMed]

20. Siegel KR, Clevenger TN, Clegg DO, Proctor DA, Proctor CS (2018) Adipose stem cells incorporated in fibrin clot modulate expression of growth factors. Arthroscopy 34: 581-591. [PubMed]

21. Lombrado E, Dela Rosa O, Mancheno-Corvo $P$, Ramirez C, Büscher D, et al (2009) Toll-like receptor-mediated signaling in human adipose-derived stem cells: implications for immunogenicity and immunosuppressive potential. Tissue Eng Part A 15: 1579-1589. [PubMed]

22. Mitchell JB, McIntosh K, Zvonic S, Garrett S, Floyd ZE, et al. (2006) Immunophenotype of human adipose-derived cells: temporal changes in stromal-associated and stem cell-associated markers. Stem Cells 24: 376-385. [PubMed]

23. Izadpanah R, Trygg C, Patel B, Kriedt C, Dufour J, et al. (2006) Biologic properties of mesenchymal stem cells derived from bone marrow and adipose tissue. J Cell Biochem 99: 1285-1297. [PubMed]
24. Bogdanova A, Berzins U, Nikulshin S, Skrastina D, Ezerta A et al. (2014) Characterization of human adipose-derived stem cells cultured in autologous serum after subsequent passaging and long term cryopreservation. J Stem Cells 9: 135-148. [PubMed]

25. Mashiko T, Wu SH, Kanayama K, Asahi R, Shirado T, et al. (2018) Biological properties and therapeutic value of cryopreserved fat tissue. Plast Reconstr Surg 141: 104-115. [PubMed]

26. James AW, Levi B, Nelson ER, Peng M, Commons GW, et al. (2011) Deleterious effects of freezing on osteogenic differentiation of human adipose-derived stromal cells in vitro and in vivo. Stem Cells Dev 20: 427-439. [PubMed]

27. Hoogduijn MJ, de Witte SF, Luk F, van den Hout-van Vroonhoven MC Ignatowicz L, et al. (2016) Effects of freeze-thawing and intravenous infusion on mesenchymal stromal cell gene expression. Stem Cells Dev 25: 586-597. [PubMed]

28. Irioda AC, Cassilha R, Zocche L, Francisco JC, Cunha RC, et al. (2016) Human adipose-derived mesenchymal stem cells cryopreservation and thawing decrease a4-integrin expression. Stem Cells Int 2016: 2562718. [PubMed]

29. Yong KW, Pingguan-Murphy B, Xu F, Abas WA, Choi JR, et al. (2015) Phenotypic and functional characterization of long-term cryopreserved human adipose-derived stem cells. Sci Rep 5: 9596. [PubMed]

30. Goh BC, Thirumala S, Kilroy G, Devireddy RV, Gimble JM (2007) Cryopreservation characteristics of adipose-derived stem cells: maintenance of differentiation potential and viability. J Tissue Eng Regen Med 1: 322-324. [PubMed]

31. Devitt SM, Carter CM, Dierov R, Weiss S, Gersch RP, et al. (2015) Successfu isolation of viable adipose-derived stem cells from human adipose tissue subject to long-term cryopreservation: positive implications for adult stem cellbased therapeutics in patients of advanced age. Stem Cells Int 2015: 146421

32. Roato I, Alotto D, Belisario DC, Casarin S, Fumagalli M, et al. (2016) Adiposederived mesenchymal stem cells viability and differentiating features for orthopedic reparative applications: Banking of adipose tissue. Stem Cells In 2016: 4968724. [PubMed]

33. Coleman SR (2006) Structural fat grafting: more than a permanent filler. Plast Reconstr Surg 118: 108-120. [PubMed]

34. Thirumala S, Zvonic S, Floyd E, Gimble JM, Devireddy RV (2005) Effect of various freezing parameters on the immediate post-thaw membrane integrity of adipose tissue-derived adult stem cells. Biotechnol Prog 21: 1511-1524. [PubMed]

35. Aksu AE, Rubin JP, Dudas JR, Marra KG (2008) Role of gender and anatomica region on induction of osteogenic differentiation of human adipose-derived stem cells. Ann Plast Surg 60: 306-322. [PubMed]

36. Jurgens WJFM, Oedayrajsingh-Varma MJ, Helder MN, Zandiehdoulabi B Schouten TE, et al. (2008) Effect of tissue-harvesting site on the yield of stem cells derived from adipose tissue: implications for cell-based therapies. Cell Tissue Res 332: 415-426. [PubMed]

37. Carvalho PP, Wu X, Yu G, Dias IR, Gomes ME, et al. (2011) The effect of storage time on adipose-derived stem cell recovery from human lipoaspirates. Cells Tissues Organs 194: 494-500. [PubMed]

38. Moscatello DK, Dougherty M, Narins RS, Lawrence N (2005) Cryopreservation of human fat for soft tissue augmentation: viability requires the use of cryoprotectant and controlled freezing and storage. Dermatol Surg 31: 1506 1510. [PubMed]

39. Conti G, Jurga M, Benati D, Bernardi P, Mosconi E, et al. (2015) Cryopreserved subcutaneous adipose tissue for fat graft. Aesthetic Plast Surg 39: 800-817. [PubMed]

40. Bourin P, Bunnell BA, Casteilla L, Dominici M, Katz AJ, et al. (2013) Stroma cells from the adipose tissue-derived stromal vascular fraction and culture expanded adipose tissue-derived stromal/stem cells: a joint statement of the International Federation for Adipose Therapeutics and Science (IFATS) and the International Society for Cellular Therapy (ISCT). Cytotherapy 15: 641-648. [PubMed]

41. Pachón-Peña G, Yu G, Tucker A, Wu X, Vendrell J, et al. (2011) Stromal stem cells from adipose tissue and bone marrow of age-matched female donors display distinct immunophenotypic profiles. J Cell Physiol 226: 843-851. [PubMed] 
Citation: Othmani AE, Rouam S, Abbad A, Erraoui C, Harriba S, et al. (2019) Cryopreservation Impacts Cell Functionality of Long Term Expanded Adipose-Derived Stem Cells. Stem Cell Res Ther 9: 445. doi: 10.4172/2157-7633.1000445

Page 8 of 8

42. Khong D, Li M, Singleton A, Chin LY, Mukundan S, et al. (2018) Orthogonal potency analysis of mesenchymal stromal cell function during ex vivo expansion. Exp Cell Res 362: 102-110. [PubMed]

43. Park CW, Kim KS, Bae S, Son HK, Myung PK, et al. (2009) Cytokine secretion profiling of human mesenchymal stem cells by antibody array. Int J Stem Cells 2: 59-68. [PubMed]

44. Dabrowski FA, Burdzinska A, Kulesza A, Sladowska A, Zolocinska A, et al. (2017) Comparison of the paracrine activity of mesenchymal stem cells derived from human umbilical cord, amniotic membrane, and adipose tissue. J Obstet Gynaecol Res 43: 1758-1768. [PubMed]

45. Hunter CA, Jones SA (2015) IL-6 as a keystone cytokine in health and disease. Nat Immunol 16: 448-457. [PubMed]

46. O'Neill LA, Bowie AG (2007) The family of five: TIR-domain-containing adaptors in Toll-like receptor signaling. Nat Rev Immunol 7: 353-364. [PubMed]

47. Salgado AJBOG, Reis RLG, Sousa NJC, Gimble JM (2010) Adipose tissuederived stem cells secretome: soluble factors and their roles in regenerative medicine. Curr Stem Cell Res Ther 5: 103-110. [PubMed]

48. Kilroy GE, Foster SJ, Wu X, Ruiz J, Sherwood S, et al. (2007) Cytokine profile of human adipose-derived stem cells: expression of angiogenic, hematopoietic, and pro-inflammatory factors. J Cell Physiol 212: 702-709. [PubMed]

49. Wu Y, Hoogduijn MJ, Baan CC, Korevaar SS, de Kuiper R, et al. (2017) Adipose tissue-derived mesenchymal stem cells have a heterogenic cytokine secretion profile. Stem Cells Int 2017: 4960831. [PubMed]

50. Lee JW, Fang X, Krasnodembskaya A, Howard JP, Matthay MA (2011) Concise review: Mesenchymal stem cells for acute lung injury: The role of paracrine soluble factors. Stem Cells 29: 913-919. [PubMed] 